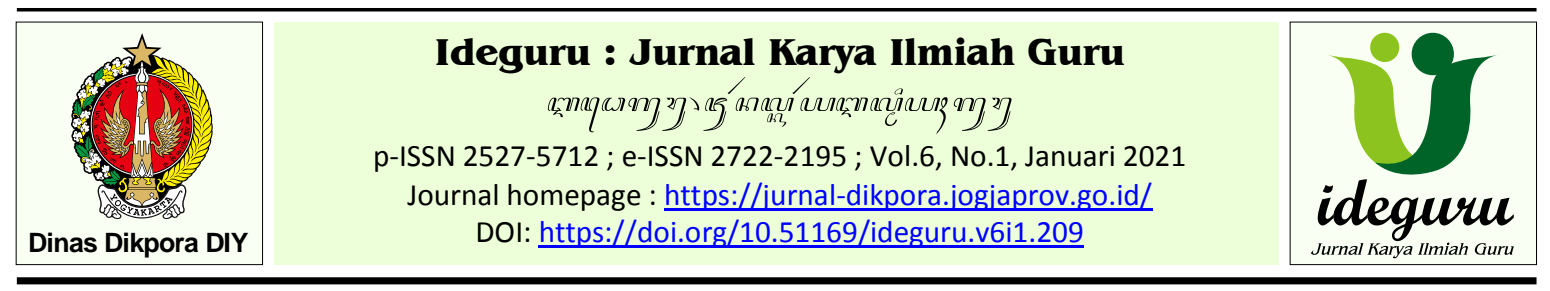

Artikel Penelitian - Naskah dikirim: 18/01/2021 - Selesai revisi: 17/02/2021 - Disetujui: 23/02/2021 - Diterbitkan: 15/03/2021

\title{
Pembelajaran Problem Based Learning Berbantuan Crossword Puzzle untuk Meningkatan Motivasi dan Hasil Belajar Sosiologi
}

\author{
Herdiwati \\ SMA Negeri 2 Yogyakarta \\ herdiwatilukita@gmail.com
}

\begin{abstract}
Abstrak: Tujuan penelitian untuk mengetahui peningkatan motivasi dan hasil belajar sosiologi pada penerapan model Problem Based Learning berbantuan media crossword puzzle. Pembelajaran model Problem Based Learning berbantuan media crossword puzzle untuk mata pelajaran sosiologi agar menarik, mempermudah belajar dan memahami materi ajar dengan kata-kata kunci atau terminologi yang terdapat pada materi. Siswa membuat media crossword puzzle secara kelompok, dan menjawab pertanyaan pada media crossword puzzle secara kelompok maupun individu. Teknis analisa data dengan tekhnik deskriptif kualitatif dalam proses belajar mengajar dan deskriptif kuantitatif dengan kriteria hasil belajar yang diperoleh melalui evaluasi. Penggunaan pembelajaran model Problem Based Learning berbantuan media crossword puzzle dapat meningkatkan motivasi belajar siswa yaitu pada siklus I sebesar $74,78 \%$ dan pada siklus II sebesar $80,76 \%$. Sedangkan hasil belajar pada siklus I diperoleh rata-rata sebesar 8,6 dan siklus II rata-rata 8,9.
\end{abstract}

Kata Kunci : problem based learning, crossword puzzle, motivasi, hasil belajar

\section{Problem Based Learning Assisted with Crossword Puzzle to Improve Motivation and Sociology Learning Outcomes}

\begin{abstract}
The research objective was to determine the increase in motivation and sociology learning outcomes in the application of the Problem Based Learning model assisted by crossword puzzle media. The learning model of Problem Based Learning is assisted by crossword puzzle media for interesting sociology subjects, making it easier to learn and understand the teaching material with the keywords or terminologi it finds in the material. Students make crossword puzzle media in groups, and answer questions on the crossword puzzle media in groups or individually. Technical analysis of data with qualitative descriptive techniques in the teaching and learning process and quantitative descriptive with the criteria of learning outcomes obtained through evaluation. The use of Problem Based Learning model with crossword puzzle media can increase the learning motivation of students, namely in cycle I, $74.78 \%$ and cycle II, $80.76 \%$. Meanwhile learning outcomes for the first cycle an average of 8.6 and the second cycle an average of 8.9. Keywords: problem based learning, crossword puzzle, motivation, learning outcomes
\end{abstract}

\section{Pendahuluan}

Peningkatan motivasi dan hasil belajar diperlukan pada proses pembelajaran agar kompetensi yang dimiliki setiap siswa berkembang optimal. Tantangan tersendiri bagi guru untuk dapat memberi layanan yang baik pada semua siswa sehingga dapat mencapai kompetensi yang seharusnya. Oleh karena itu diperlukan peran guru untuk memiliki inovasi dalam mengajar agar tidak monoton dengan menggunakan metode ceramah. Pada materi sosial, penggunaan metode ceramah akan membuat siswa bosan dan tentu saja menghambat penguasaan materi. Guru dituntut menggunakan metode dan model pembelajaran yang tepat (Zaini, 2007: 78) agar siswa termotivasi untuk belajar dengan baik sehingga dapat meningkatkan hasil belajarnya dan dapat mencapai KKM yang ditetapkan atau bahkan lebih baik lagi. Berdasarkan hal di atas yang dapat dilakukan guru agar siswa dapat mencapai kompetensi yang seharusnya, adalah mengembangkan proses belajar mengajar dengan penggunaan media yang menarik agar tujuan pembelajaran yang disampaikan tercapai sesuai dengan kriteria yang ditentukan.

Dalam model pembelajaran Problem Based Learning siswa belajar mandiri untuk mengembangkan pengetahuan yang sudah diterima. Permasalahan yang diberikan guru adalah merupakan hal yang baru dan ada di lingkungan siswa, sehingga mudah dipahami dan diterapkan dalam kehidupan. Siswa berusaha memecahkan masalah dengan mencari sendiri 
melalui buku atau sumber informasi yang lain. Guru membentuk kelompok belajar agar terjadi interaksi alamiah, siswa bisa saling berbagi mengembangkan pengetahuan secara bersamasama dan belajar berbagi tugas dengan tujuan yang jelas. Problem Based learning adalah metode yang dapat dimanfaatkan oleh guru pada proses belajar-mengajar, dengan harapan siswa tidak hanya mempelajari ilmu pengetahuan tetapi juga memiliki keterampilan dalam memecahkan masalah (Kamdi, 2007: 770).

Media perlu digunakan guru dalam proses pembelajaran guna mempermudah kerumitan atau memperjelas keabstrakan materi dalam mencapai tujuan pembelajaran. Djamaroh (2010: 120). Dalam proses pembelajaran guru akan selalu berusaha agar siswa dapat menerima penjelasan materi sesuai tujuan dari pembelajaran yang tertuang pada perencanaan Rencana Pelaksanaan Pembelajaran (RPP). Siswa akan mudah tertarik dan aktif dalam mengikutin proses belajar-mengajar apabila guru memanfaatkan media dengan tepat sesuai dengan materi pelajaran yang diberikan, sehingga akan tercapai tujuan pembelajaran dengan baik.

Permainan Crossword puzzle dalam kehidupan sehari-hari dikenal sebagai teka-teki silang yang terdiri dari serangkaian kotak-kotak kosong mendatar dan menurun. yang didesain sedemikian rupa yang berbentuk segi empat yang terdiri dari kotak-kotak yang berwana hitam putih, dilengkapi 2 lajur, dan dilengkapi dengan pertanyaan-pertanyaan sesuai dengan materi yang dipersiapkan. Dengan pemanfaatan media yang tepat pada proses belajar-mengajar, siswa akan tertarik untuk belajar dan berperan aktif dengan sepenuh hati, sehingga tujuan pembelajaran yaitu penguasaan materi oleh siswa akan lebih mudah tercapai dengan lebih baik.

Dalam proses belajar motivasi merupakan hal yang penting karena mendorong siswa melakukan kegiatan-kegiatan untuk tujuan tertentu yang hendak dicapai (Sanjaya, 2010: 249). Motivasi siswa pada proses belajarmengajar sangat diperlukan agar dapat mengikuti pembelajaran dengan optimal. Peran guru sangat besar untuk menumbuhkan motivasi siswa yang akan tumbuh sejalan dengan proses pembelajaran yang dilaksanakan pada kelasnya. Pemanfaatan media dan model pembelajaran yang menarik mendorong siswa bersemangat dan gembira mengikuti proses belajar mengajar, yang tentunya akan mempengaruhi hasil belajar.

Proses belajar terjadi melalui pola perilaku, pola berpikir dan kemampuan fisik yang dilakukan tanpa disadari akan memunculkan suatu perubahan pada perilaku seseorang. Demikian juga yang terjadi pada siswa dalam proses belajar akan mengalami perubahan dari tidak tahu menjadi tahu sebagai hasil belajar. Untuk mengetahui perkembangan dalam proses belajar, guru sebaiknya melaksanakan tes yang kriteria keberhasilannya diukur dalam bentuk angka untuk mengetahui hasil belajar siswa pada setiap akhir pelajaran (Dimyati dan Mudjiono, 2006: 19).

Berdasarkan latar belakang yang didukung dengan tinjauan pustaka di atas, maka dilaksanakan penelitian dengan judul "Pembelajaran Problem Based Learning berbantuan Crossword Puzzle untuk meningkatan motivasi dan hasil belajar sosiologi di Kelas XI IIA 3 SMA Negeri 2 Yogyakarta tahun ajaran 20192020".

Rumusan masalah dalam penelitian ini, pertama, apakah melalui model Problem Based Learning dengan media crossword puzzle dapat meningkatkan motivasi sosiologi di Kelas XI IIA 3 SMA Negeri 2 Yogyakarta? Kedua, apakah melalui model Problem Based Learning dengan media crossword puzzle dapat meningkatkan hasil belajar sosiologi di Kelas XI IIA 3 SMA Negeri 2 Yogyakarta?

Tujuan penelitian adalah: 1) Melalui model Problem Based Learning dengan media crossword puzzle dapat meningkatkan motivasi belajar sosiologi di Kelas XI IIA 3 SMA Negeri 2 Yogyakarta, 2) Melalui model Problem Based Learning dengan media crossword puzzle dapat meningkatkan hasil belajar sosiologi di Kelas XI IIA 3 SMA Negeri 2 Yogyakarta. Penelitian ini diharapkan bermanfaat baik secara teoritis sebagai teori baru tentang motivasi dan prestasi belajar sebagai dasar penelitian selanjutnya, maupun manfaat praktis baik siswa, guru maupun sekolah.

\section{Metode Penelitian}

Penelitian Tindakan Kelas (PTK) atau disebut "classroom action research" (Suharsimi, 2006) dilaksanakan dengan tujuan memperbaiki proses pembelajaran di kelas. Pelaksanaanya perlu adanya kerjasama, bantuan dari guru mata pelajaran sejenis untuk terciptanya perubahan dan siswa sebagai obyeknya.

Penelitian ini dilaksanakan selama 4 bulan, dari bulan Agustus - Oktober 2019 yang terbagi dalam dua siklus. Siklus I dilaksanakan pada tanggal 19 Agustus - 17 September 2019, sedangkan siklus II dilaksanakan pada tanggal 21 September - 15 Oktober 2019.

Penelitian dilakukan di kelas XI IIA 3 SMA Negeri 2 Yogyakarta, dengan subjek penelitian 
sebanyak 32 siswa. Penelitian dilakukan di kelas ini karena Sosiologi merupakan pelajaran lintas minat, yang siswanya cenderung lebih mengutamakan belajar mata pelajaran sesuai dengan bidang jurusannya. Model spiral yang digunakan dalam penelitian ini, terdiri dari dua kali tindakan secara berulang/siklus, setiap siklus terdiri dari empat tindakan yaiyu perencanaan, tindakan, observasi dan refleksi (Kemmis dan Taggart dalam Wina, 2008: 20). Tindakan dilaksanakan dengan dua siklus yang setiap siklus terdiri dari tiga pertemuan.

Tahap Rencana tindakan: 1) Membuat Rencana Pelaksanaan Pembelajaran tentang materi Permasalahan Sosial sesuai dengan model pembelajaran yang akan digunakan media crossword puzzle, 2) Membuat lembar observasi pengelolaan kelas dan guru mengajar, 3) Membuat lembar observasi siswa tentang perilaku siswa dalam pelaksanaan pembelajaran metode diskusi dengan media crossword puzzle, 4). Membuat media crossword puzzle tentang permasalahan sosial, 5) Membuat angket respon siswa terhadap penerapan metode diskusi dengan media crossword puzzle.

Tahap pelaksanaan tindakan: 1) Berdoa dan mengabsen, 2) Membangkitkan motivasi siswa terhadap materi yang akan disampaikan, 3) Menyampaikan tujuan dan media pembelajaran yang akan digunakan, 4) Menjelaskan konsep materi yang akan disampaikan, 5) Memberi kesempatan siswa menanyakan hal-hal yang belum jelas, 6) Mengorganisasi siswa ke dalam kelompok belajar yang terdiri 5-6 siswa, 7) Menyampaikan masalah untuk didiskusikan, 8) Memperhatikan siswa yang melakukan diskusi dalam setiap kelompok, 9) Membimbing siswa dalam menjawab pertanyaan dan menyampaikan pendapat, tentang materi yang esensial sebagai kata kunci atau terminologi, 10) Membimbing siswa membuat media crossword puzzle. 11) Memoderatori presentasi kelompok tentang hasil media crossword puzzle, 12) Menyimpulkan hasil kegiatan belajar, 13) Menutup kegiatan pembelajaran dengan salam.

Pada tahap observasi, observasi dilaksanakan pada setiap siklus selama proses pembelajaran menggunakan metode diskusi dengan model crossword puzzle bersama kolaborator yaitu Sapto Wahyu. S.Sos. Lembar alat observasi yang digunakan pada penelitan tindakan yang digunakan guru yang terdiri dari: 1) lembar observasi pengelolaan kelas dan guru mengajar, 2) pembelajaran diskusi dengan media crossword Puzzle, 3) lembar observasi kegiatan peri laku siswa dalam metode pembelajaran diskusi dengan media crossword puzzle, 4) Media crossword puzzle sebagai alat tes untuk mengetahui hasil belajar siswa materi permasalahan sosial.

Pada tahap refleksi, data hasil obesrvasi dianalisa oleh guru dan kolaborator dengan langkah-langkah sebagai berikut; 1) Merencanakan pelaksanakan tindakan yang belum berjalan dengan baik, 2) Siswa diberi kesempatan untuk mengemukakan pendapat dan usul-usul untuk perbaikan, 3) Kolaborator menyampaikan kepada guru maupun siswa hasil pengamatan tindakan, 4) Guru dan kolaborator melakukan evaluasi tindakan pada siklus satu untuk melakukan perubahan pada siklus dua agar hambatan yang terjadi pada siklus satu diperbaiki dengan tindakan yang lebih tepat, setelah melihat hasil dari tindakan pada siklus satu kemudian menentukan rancangan tindakan yang akan dilakukan untuk pertemuan pada siklus kedua sebagai penguatan dan memperbaiki langkah terhadap hambatan / kesulitan yang ditemukan pada pertemuan pada siklus yang akan dilaksanakan selanjutnya. 5) Membuat sarana tindakan yaitu: RPP, lembar observasi guru, lembar observasi perilaku siswa pada proses pembelajaran, membuat media crossword puzzle untuk instrumen/ tes, membuat angket respon siswa terhadap penerapan metode diskusi dengan media crossword puzzle.

Hasil observasi yang dilakukan oleh guru bersama kolaborator pada proses pembelajaran yang dilakukan pada setiap siklus masing-masing dengan tiga pertemuan, yaitu: 1) Pengumpulan data dengan observasi secara langsung oleh kolaborator dalam setiap siklus pada proses belajar mengajar, 2) Pengumpulan data dengan observasi tindakan siswa dalam pembelajaran, 3) Pengumpulan data melalui angket respon terhadap pelaksanaan pembelajaran, 4) Untuk mengetahui hasil belajar siswa digunakan instrumen berupa soal tes.

Teknik analisis data yang digunakan meliputi; 1) Teknis deskriptif kualitatif, yakni dengan mendiskripsikan data mengenai pelaksanaan proses belajar mengajar dari perencanaan, pelaksanaan tindakan, hasil observasi dan refleksi dari setiap siklus. Data tentang kualitas pembelajaran juga dideskripsikan secara rinci berdasarkan hasil observasi dengan pedoman observasi yang telah disiapkan untuk guru dan siswa, 2) Teknik diskriptif kuantitatif dengan kriteria proses belajar mengajar yang diapatkan melalui evaluasi dengan interval, yaitu: $\leq 75$ (kurang), 75-82 (cukup), 83-92 (baik), dan 93-100 (amat baik), didapatkan melalui evaluasi, yang diperoleh dengan instrumen berupa tes. 


\section{Hasil dan Pembahasan}

Untuk meningkatkan motivasi dan hasil belajar siswa yang dilakukan guru adalah dengan menerapkan model Problem Based Learning dengan media crossword puzzle Pada tahap perencanaan ini peneliti menyusun instrumen yang akan digunakan dalam pelaksanaan tindakan, meliputi: 1) Silabus, 2) Rencana Pelaksanaan Pembelajaran (RPP), 3) lembar observasi pelaksanaan tindakan guru dalam menerapkan metode dengan media crossword puzzle, 4) lembar observasi motivasi siswa, 5) angket respon siswa terhadap penerapan media crossword puzzle dan 7) instrumen tes akhir dalam bentuk crossword puzzle.

Pertemuan pertama siklus 1 berlangsung pada hari Selasa, tanggal 3 September 2019 adalah sebagai berikut: a) Guru mengawali pembelajaran dengan mengucapkan salam, berdoa, mengabsen ,menanyakan dan mengulang materi yang sudah diajarkan pada pertemuan sebelumnya, menyampaikan materi yang akan diajarkan sesuai kompetensi dasar, tujuan dan kegiatan pembelajaran yang akan dilaksanakan, sesuai dengan yang sudah direncanakan pada rencana pelaksanaan pembelajaran, b) Membagi kelas menjadi enam kelompok secara heterogen, c) Membagi permasalahan pada setiap kelompok yang berisi materi pengertian permasalahan sosial, d) Siswa mendiskusikan materi yang diberikan guru, e) siswa menyusun laporan hasil diskusi kelompok dalam bentuk kata-kata kunci, terminologi atau kata-kata penting tentang materi untuk dipaparkan ke media crossword puzzle, f) Guru bertindak sebagai fasilitator dalam kegiatan pembelajaran yaitu mengarahkan dan membimbing diskusi.

Tindakan pertemuan kedua berlangsung pada hari Rabu tanggal 10 September 2019. Siswa bersama kelompoknya melaksanakan diskusi kelompok dengan menggunakan media yang disiapkan. Dalam kegiatan ini guru sebagai fasilitator mengarahkan kegiatan, yaitu: a) Siswa bersama kelompoknya membuat soal-soal yang ada terminologi atau nama-nama tentang materi yang diketemukan pada pertemuan pertama siklus I, b) hasil crossword puzzle kelompok dikumpulkan c) setiap kelompok mengerjakan media crossword puzzle milik kelompok lain secara acak, d) Kelompok mempresentasikan hasil pekerjaannya.

Sedangkan pertemuan ketiga berlangsung pada hari Selasa tanggal 17 September 2019. Dengan kegiatan siswa bersama kelompoknya mengerjakan media crossword puzzle dari guru sebagai tes akhir.
Berdasarkan hasil observasi aktivitas guru dalam melaksanakan langkah-langkah proses pembelajaran sesuai dengan rencana pelaksanaan pembelajaran dengan model Problem Based Learning media crossword puzzle, yang telah direncanakan dalam Rencana Pelaksanaan Pembelajaran (RPP). Data hasil observasi guru terdapat pada tabel 1 .

Tabel 1. Pelaksanaan observasi siklus I

\begin{tabular}{|c|c|c|c|c|}
\hline \multirow{2}{*}{$\begin{array}{l}\text { Perte- } \\
\text { muan }\end{array}$} & \multirow{2}{*}{$\begin{array}{c}\text { Jumlah } \\
\text { aspek } \\
\text { yang } \\
\text { dinilai }\end{array}$} & \multicolumn{2}{|c|}{ Pelaksanaan } & \multirow{2}{*}{ ঐ氖高 } \\
\hline & & Ya & Tidak & \\
\hline 1 & 20 & 18 & 2 & 90 \\
\hline 2 & 20 & 17 & 3 & 85 \\
\hline Jumlah & 40 & 35 & 5 & 175 \\
\hline \multicolumn{2}{|c|}{ Rata-rata \% } & 87,5 & 12,5 & 87,5 \\
\hline
\end{tabular}

Untuk mengetahui motivasi siswa di kelas baik secara individu maupun kelompok pada proses pembelajaran diperlukan kegiatan observasi. Observasi berpedoman pada penilaian sikap atau perilaku siswa saat pelaksanaan diskusi secara keseluruhan. Lembar observasi disusun berdasarkan taxonomi bloom (Darmawan, 2013: 30-39) dengan indikator sebagai berikut: a) siswa mendengarkan penjelasan yang disampaikan oleh guru, b) siswa menunjukkan sikap rasa ingin tahu, c) siswa terlibat aktif dalam kegiatan diskusi, d) siswa terlibat aktif dalam menyelesaikan masalah, e) siswa memberi kesempatan anggota kelompok lain untuk menjelaskan argumennya, f) siswa mempertahankan gagasannya dengan dasar yang ilmiah sesuai konten, g) siswa menyelesaikan tugasnya dengan tepat waktu, h) siswa berusaha berkompetisi untuk menjawab soal-soal yang ada pada crossword puzzle. Interval nilai yang digunakan adalah 1-4, dengan kriteria sebagai berikut; 1 kurang, 2 cukup, 3 baik, dan 4 amat baik. Hasil observasi motivasi siswa pada pembelajaran model Problem Based Learning dengan media crossword puzzle ini dapat dilihat pada tabel 2 .

Tabel 2. Observasi motivasi siswa pada siklus I

\begin{tabular}{cccc}
\hline Indikator & $\sum$ Skor & Rerata & $\%$ \\
\hline a & 93 & 2,89 & 72,32 \\
b & 95 & 2,96 & 74,11 \\
c & 94 & 2,96 & 74,11 \\
d & 96 & 3,00 & 75,00 \\
e & 95 & 2,96 & 74,11 \\
f & 100 & 3,11 & 77,68 \\
g & 95 & 2,96 & 74,11 \\
h & 98 & 3,07 & 76,79 \\
\hline Jumlah & 766 & 23,93 & 598,23 \\
\hline Rerata & 95,75 & 2,99 & 74,78 \\
\hline
\end{tabular}


Hasil belajar siswa pada siklus I diukur melalui tes akhir dengan media crossword puzzle. Instrumen yang digunakan adalah dalam bentuk soal crossword puzzle yang dibuat oleh guru. Hasil belajar siswa pada siklus I dapat dilihat pada tabel 3, yang menunjukan peningkatan hasil belajar siswa sebesar 1,4.

Tabel 3. Hasil belajar pra-tindakan dan siklus I

\begin{tabular}{ccc}
\hline Keterangan & $\begin{array}{c}\text { Nilai Pra- } \\
\text { Tindakan }\end{array}$ & $\begin{array}{c}\text { Nilai } \\
\text { Siklus I }\end{array}$ \\
\hline Jumlah & 2225 & 2740 \\
\hline Rata-rata & 7,2 & 8,6 \\
\hline
\end{tabular}

Refleksi dilakukan dengan berdiskusi dengan kolaborator untuk menentukan langkah tindakan yang akan dilakukan guru pada pertemuan siklus II yaitu: 1) pencapaian tindakan, guru sudah melakukan proses pembelajaran sesuai dengan rencana pelaksanaan pembelajaran yang sudah disiapkan, perlu dilakukan perbaikan, 2) Hambatan terdapat pada penguasaan materi oleh siswa yang kurang baik karena penjelasan materi dalam bentuk teks, diperlukan penguasaan materi oleh siswa dengan baik.

Pada siklus II, pertemuan pertama berlangsung pada hari Selasa, 24 September 2019. Proses penyampaian materi dilakukan menggunakan video pembelajaran, agar membantu meningkatkan motivasi belajar siswa. Pembelajaran pertemuan kedua berlangsung pada hari Selasa, 25 September 2019, dengan kegiatan pembelajaran siswa secara kelompok mempresentasikan hasil pengamatan video. Pembelajaran pertemuan ketiga berlangsung pada hari Selasa 15 Oktober 2019, dengan agenda tes secara individual. Hasil observasi pelaksanaan pembelajaran pada siklus kedua secara rinci terdapat pada tabel 4 .

Tabel 4. Pelaksanaan observasi siklus II

\begin{tabular}{|c|c|c|c|c|}
\hline \multirow{2}{*}{$\begin{array}{l}\text { Perte- } \\
\text { muan }\end{array}$} & \multirow{2}{*}{$\begin{array}{l}\text { Jumlah } \\
\text { aspek yang } \\
\text { dinilai }\end{array}$} & \multicolumn{2}{|c|}{ Pelaksanaan } & \multirow{2}{*}{$\begin{array}{c}\text { Keter- } \\
\text { laksaan } \\
\% \\
\end{array}$} \\
\hline & & Ya & Tidak & \\
\hline 1 & 20 & 18 & 2 & 90 \\
\hline 2 & 20 & 18 & 2 & 90 \\
\hline Jumlah & 40 & 36 & 4 & 180 \\
\hline & -rata \% & 90 & 10 & 90 \\
\hline
\end{tabular}

Observasi terhadap motivasi siswa dalam presentasi kelompok pada penerapan Problem Based Learning dengan media crossword puzzle, dilakukan dengan indikator berdasarkan taxonomi bloom yang diuraikan sebagai berikut: a) siswa mendengarkan penjelasan guru, b) siswa menunjukkan sikap rasa ingin tahu, c) siswa terlibat aktif dalam kegiatan diskusi, d) siswa terlibat aktif dalam menyelesaikan masalah, e) siswa memberi kesempatan anggota kelompok lain untuk menjelaskan argumennya, f) siswa mempertahankan gagasannya dengan dasar yang ilmiah sesuai konten, g) siswa menyelesaikan tugasnya dengan tepat waktu, h) siswa berusaha berkompetisi untuk menjawab soal-soal yang ada pada crossword puzzle (Darmawan, 2013: 30-39). Interval nilai yang digunakan adalah 1-4, dengan kriteria sebagai berikut; 1 kurang, 2 cukup, 3 baik, dan 4 amat baik. Hasil observasi motivasi siswa yang diperoleh dapat dilihat pada tabel 5 .

Tabel 5. Observasi motivasi siswa pada siklus II

\begin{tabular}{cccc}
\hline Indikator & $\sum$ Skor & Rerata & $\%$ \\
\hline a & 100 & 3,13 & 78,13 \\
b & 101 & 3,16 & 78,91 \\
c & 105 & 3,28 & 82,03 \\
d & 108 & 3,38 & 84,38 \\
e & 104 & 3,25 & 81,25 \\
f & 102 & 3,19 & 79,69 \\
g & 106 & 3,31 & 82,81 \\
h & 101 & 3,16 & 78,91 \\
\hline Jumlah & 827 & 25,84 & 646,09 \\
\hline Rerata & 103,38 & 3,23 & 80,76 \\
\hline
\end{tabular}

Hasil belajar siswa pada siklus II diukur menggunakan tes akhir melalui media crossword puzzle, dengan tindakan siswa mengerjakan media crossword puzzle tidak berkelompok, siswa mengerjakan secara individual. Data peningkatan hasil belajar antar siklus tersaji pada tabel 6 berikut.

Tabel 6. Hasil belajar pra-tindakan, siklus I dan siklus II.

\begin{tabular}{cccc}
\hline Keterangan & $\begin{array}{c}\text { Pra- } \\
\text { Tindakan }\end{array}$ & Siklus I & Siklus II \\
\hline Jumlah & 2225 & 2740 & 2837 \\
\hline Rata-rata & 7,2 & 8,6 & 8,9 \\
\hline
\end{tabular}

Tahap refleksi dilakukan dengan melihat observasi dari hasil indikator pada; a) motivasi belajar siswa yang ditunjukan dengan aktivitas pada waktu mengikuti proses pembelajaran pada pertemuan satu dan dua siklus II. b) Hasil belajar siswa pada materi permasalahan sosial bisa dilihat dari hasil tes pada pertemuan ketiga siklus II yang sekaligus merupakan selesainya tahap tindakan oleh guru pada kelas tersebut.

Pelaksanaan proses pembelajaran, sintak dibuat oleh guru bersama kolaborator dan dilaksanakan oleh guru yang didukung siswa dengan melaksanakan sesuai rencana yang telah disusun dalam administrasi pembelajaran. Dari rencana pelaksanaan pembelajaran pada siklus I $87,5 \%$, terlaksana dengan cukup baik sedangkan 
yang tidak atau belum dilaksanakan 12,5\%. dan pada siklus II guru telah melaksanakan proses pembelajaran sesuai yang direncanakan dalam rencana pelaksanaan pembelajaran $90 \%$, sedangkan yang tidak atau belum dilaksanakan $10 \%$.

Motivasi siswa selama pembelajaran pada siklus I diukur melalui delapan indikator berdasarkan taxonomi bloom, dengan hasil sebagai berikut: a) Siswa mendengarkan penjelasan yang disampaikan oleh guru $72,32 \%$, b) Siswa menunjukkan sikap rasa ingin tahu $74,11 \%$, c) Siswa terlibat aktif dalam kegiatan diskusi $74,11 \%$, d) Siswa terlibat aktif dalam menyelesaikan masalah $75,00 \%$, e) Siswa memberi kesempatan anggota kelompok lain untuk menjelaskan argumennya $74,11 \%$, f) Siswa mempertahankan gagasannya dengan dasar yang ilmiah sesuai konten $77,68 \%$, g) Siswa menyelesaikan tugasnya dengan tepat waktu $74,11 \%$, h) Siswa mengerjakan dan menjawab soal-soal yang ada pada crossword puzzle untuk digunakan sebagai tes akhir materi permasalahan sosial 76,79.

Aktivitas siswa pada proses pembelajaran selama siklus II terdapat peningkatan, baik dari interaksi maupun motivasi mengerjakan tugas dalam kelompok sesuai tugas yang diberikan oleh guru. Kegiatan siswa pada siklus kedua yaitu, a) Sebanyak 78,13\% siswa mempersiapkan diri untuk belajar dengan baik dengan kesediaan memperhatikan penjelasan guru dalam apersepsi. b) Perhatian siswa terkontrol dari rasa keingintahuannya terhadap penjelasan guru tentang materi pembelajaran yang akan disampaikan sebanyak 78,91\%. c) Sebanyak $82,03 \%$ respon siswa menunjukkan terlibat aktif dalam kegiatan diskusi dalam kelompoknya, d) Sebanyak $84,38 \%$ siswa terlibat aktif dalam penyelesaiaan masalah, e) Siswa juga memberi kesempatan kepada kelompok lain untuk saling menjelaskan argumentasinya dengan mempresentasikan hasil diskusinya mencapai $81,25 \%$ yang diwakili oleh siswa yang menjadi pemimpin dari kelompok tersebut. f) Sebanyak $79,69 \%$ Siswa mempertahankan gagasannya dengan dasar yang ilmiah sesuai konteks, g) Sebagian kelompok dapat menyelesaikan tugasnya dengan tepat waktu sebanyak $82,81 \%$, dan h) Sebanyak 78,91\% siswa berusaha berkompetisi untuk menjawab soal-soal yang ada pada crossword puzzle.

Proses penilaian belajar pada siklus I dan II dilaksanakan dengan pengawasan guru secara intensif agar diperoleh hasil yang outentik dan obyektif. Pelaksanaan tes akhir yang dijadikan sebagai ulangan harian pada siklus I dilaksanakan secara kelompok sekaligus sebagai uji coba terhadap hasil belajar dari penerapan media pembelajaran crossword puzzle. Sedangkan pelaksanaan tes akhir pada siklus II dilaksanakan secara individu.

Guru tidak hanya mendapatkan hasil belajar berupa nilai kognitif saja tetapi juga mendapatkan data tentang perilaku siswa pada waktu mengerjakan soal secara kelompok, interaksi dan kerja sama dengan teman dalam menyelesaikan tugas pada kelompok masingmasing siswa, hal ini memungkinkan anak didik memperoleh pengetahuan dan keterampilan. (Djamaroh, 2010: 120). Setelah dilakukan koreksi terdapat peningkatan yang cukup baik dan menggembirakan. Penilaian kognitif untuk siklus I hasil belajar siswa rata-rata mencapai 8,6 lebih baik dari sebelum dilakukan tindakan yang rata-rata baru mencapai 7,2. Pada siklus II hasil belajar siswa terjadi peningkatan dengan nilai rata-rata 9,1 .

Respon siswa terhadap aktivitas pembelajaran dengan model Problem Based Learning dengan media crossword puzzle, yaitu $81,25 \%$ dari jumlah siswa menyatakan tertarik sehingga senang dalam mengikuti proses pembelajaran, $72,65 \%$ siswa tertarik dengan media yang digunakan sehingga cukup aktif mengikuti proses pembelajaran, 47,65\% agak tertarik dengan penerapan media crossword puzzle dan cukup aktif dalam proses pembelajaran, sedangkan $41,40 \%$ siswa kurang tertarik sehingga kurang aktif dalam proses pembelajaran.

Penelitian ini sejalan dengan penelitian yang dilakukan oleh Mohammad Andi Wasgito guru Seni Budaya SMP Negeri 2 Kalianget, Madura. Hasil penelitian tersebut mendeskripsikan langkah-langkah pengembangan media permainan teka-teki silang yang dapat mempengaruhi keaktivan dan hasil belajar siswa (Wasgito, 2016).

\section{Simpulan dan Saran}

Berdasarkan penelitian dan pembahasan maka dapat disimpulkan sebagai berikut. Pertama, model Problem Based Learning dengan media crossword puzzle dapat meningkatkan motivasi belajar siswa khususnya pada mata pelajaran sosiologi. Hal ini dapat dilihat dari hasil observasi delapan indikator penilaian afeksi pada waktu dilakukan tindakan yaitu: pada siklus I mencapai hasil 74,78\% dan siklus II mengalami peningkatan $5.98 \%$ menjadi $80,76 \%$.

Kedua, model Problem Based Learning dengan media crossword puzzle dapat meningkatkan hasil belajar siswa khususnya pada mata pelajaran sosiologi. Sebelum dilakukan 
tindakan rata-rata hasil belajar pada ulangan harian 7,2. Setelah dilakukan tindakan, hasil belajar pada siklus I rata-rata mencapai 8,6 dan pada siklus II terjadi peningkatan rata-rata hasil belajar menjadi 9,1 .

Sebagai saran dari refleksi penelitian ini adalah sebagai berikut. Pertama, pelaksanaan metode dengan media crossword puzzle lebih baik diterapkan pada mata pelajaran sosial dengan materi yang heterogen dan luas, karena media ini membutuhkan terminologi. Kedua, sebaiknya guru dalam penerapan media crossword puzzle memberi penjelasan materi dengan detail, sehingga mempermudah siswa mengerjakan crossword puzzle.

Inovasi sekecil apapun harus terus dilakukan, terlebih dalam masa pandemi dimana pembelajaran dilaksanakan secara daring. Best practice tentang pengecekan plagiasi terhadap produk pembelajaran menulis peserta didik dalam pembelajaran daring ini merupakan salah satu bentuk inovasi kecil yang sulit dilaksanakan ketika pembelajaran dilaksanakan secara tatap muka konvensional.

Setelah melalui serangkaian proses pembelajaran daring, dapat disimpulkan bahwa 1) ditinjau dari ketercapaian tujuan pembelajaran yang diukur berdasarkan perolehan skor, pembelajaran ini mencapai ketuntasan klasikal 96\% dengan nilai rerata 86, nilai tertinggi 97 , nilai terendah $65 ; 2$ ) ditinjau dari persentase keunikan produk, 53\% peserta didik masuk dalam kategori $100 \%$ unik. Selebihnya masih berada pada keunikan dengan persentasi pada rentang 0 s.d 99\%. Peserta didik yang dinyatakan tidak tuntas disebabkan oleh keterlambatan pengiriman dan kesalahan teknik pengiriman.
Perkembangan, perubahan, dan ketidakpastian yang makin tidak dapat diprediksi seharusnya memacu peserta didik untuk menjadi pembelajar yang mandiri. Apapun moda pembelajaran, peserta didik seharusnya tetap bisa berkomitmen terhadap belajarnya. Konsep pembelajaran zaman now bahwa siapa pun bisa jadi guru, di mana pun bisa jadi kelas harus benar-benar tertanam pada diri peserta didik. Terkait dengan topik best practice ini, peserta didik sudah harus mulai mengutamakan keaslian karya sendiri dengan mengedepankan etika menulis yang diterima secara global.

\section{Daftar Pustaka}

Darmawan, I. P. A., \& Sujoko, E. (2013). Revisi Taksonomi Pembelajaran Benyamin S. Bloom. Satya Widya, 29(1), 30-39.

Dimyati \& Mudjiono (2006), Belajar dan Pembelajaran, Jakarta: Rineka Cipta.

Djamaroh, SB (2010), Startegi Belajar Mengajar, Jakarta: Rineka Cipta.

Kamdi, W dkk. (2007). Model-Model Pembelajaran Inovatif. Universitas Negeri Malang. Malang.

Suharsimi. A dan Supardi, S (2006), Penelitian Tindakan Kelas. Jakarta: Bumi Aksara.

Wasgito, MA. (2016). Pengembangan Media Permainan Teka-Teki Silang Untuk Peningkatan Keaktivan dan Hasil Belajar. Karya Tulis Tidak Diterbitkan. SMP Negeri 2 Kalianget, Madura.

Wina, S (2008), Strategi Pembelajaran, Jakarta: Kencana Prenada.

Zaini, H (2007). Metode Belajar Strategi Belajar, Yogyakarta: Pustaka Insan Madani. 